\title{
Offshore Distribution Patterns of the Cyanobacterium Trichodesmium erythraeum Ehrenberg and Associated Phyto- and Bacterioplankton in the Southern Atlantic Coast (Paraná, Brazil)
}

\author{
Adriana Siqueira*, Hedda Elisabeth Kolm and Frederico Pereira Brandini \\ Marine Study Center; Federal University of Paraná - UFPR; C. P. 50.002; 83255-000; a.siqueira@ufpr.br; Pontal
} do Sul - PR - Brasil

\begin{abstract}
Studies were carried out on Thrichodesmium erythraeum occurring on the inner shelf in the state of Paraná;Brazil. Temperature, salinity, rainfall, wind velocity, total bacteria, bacterial biomass, chlorophyll-a, phytoplankton, Anabaena sp., Merismopedia sp. and $\underline{\mathrm{T}}$. erythraeum densities were measured in surface water. Centric and pennate diatoms, Anabaena sp. and Merismopedia sp. were most abundant at $15 \mathrm{~m}$ isobath, while dinoflagellate abundance was relatively constant among stations. Similarly, total bacterial densities were relatively homogeneous throughout the sampling area, suggesting that blooms of $\underline{\mathrm{T}}$. erythraeum were not yet in the senescent phase. Results showed that $\underline{\mathrm{T}}$. erythraeum was capable of surviving in relatively inhospitable environmental conditions, due to its ability to fix nitrogen and to photosynthesis at high light intensities.
\end{abstract}

Key words: Trichodesmium erythraeum, bloom, cyanobacteria, phytoplankton, south Brazil

\section{INTRODUCTION}

Cyanobacteria are prokaryotes, gram-negative, photosynthetic microorganisms. Species with the ability to fix nitrogen are included in the Eubacteria group (Barbrook et al., 1998; Doyle, 1998). Cyanobacteria are distributed globally in soils, freshwater and marine environments. In marine environments, cyanobacteria may form blooms, similar to those of microalgae, which are often toxic to other organisms. Blooms are usually associated with eutrophication caused by the discharge of untreated domestic sewage and so primarily occur in estuaries and coastal waters. Yet, bloom complexity cause some authors to view the anthropogenic nutrient sources as secondary triggering factors (Richardson, 1997). The genus Trichodesmium is known to bloom frequently in calm tropical and sub-tropical waters (Bidandda, 1997).

The dynamics of Trichodesmium and dinoflagellates blooms occurring along the Brazilian shelves have been studied by Satô et al. (1963) in Pernambuco (northeastern state of Brazil), Rosa and Bucelato (1981) in Rio Grande do Sul (southern state of Brazil) and a few other studies in the state of São Paulo (southern Brazil; Gianesella-Galvão et al., 1995; Kutner and Sassi, 1978).

The first large-scale descriptions of the distribution of Trichodesmium in southeastern Brazilian shelves demonstrated that relatively high

*Author for correspondence 
concentrations of Trichodesmium occur in areas dominated by tropical waters and that concentrations decline greatly in winter, when subAntarctic waters reach the region (Brandini, 1988). On the shelf in the state of Paraná, large concentrations of cyanobacteria, mostly Trichodesmium sp., were recorded in November (late southern spring) 1987 at the water surface between the 25 and $60 \mathrm{~m}$ isobaths, and in the subsurface layers between the 100 and $300 \mathrm{~m}$ isobaths (Brandini et al., 1988). Also, blooms of $T$. erythraeum were observed in the states of São Paulo and Paraná (southern Brazil), which were affected by the tropical waters of the Brazil Current (Fernandes and Brandini, 1999).

In February 2000, a bloom of T. erythraeum with ca. $100 \mathrm{~km}$ of extension was observed at about 80 $\mathrm{km}$ from the coast, between the Superagüi Island (Paraná) and southern Cardoso Island (São Paulo) (CETESB, 2000). Due to the scarcity of studies of southern cyanobacterial blooms and the ecological importance of these nitrogen-fixing organisms, we initiated the study described herein. Our objective was to investigate the distribution and seasonal dynamics of $T$. erythraeum blooms and the associated phytoplankton groups, and attempt to associate these dynamics with variations in the biotic and abiotic environment.

\section{STUDY AREA}

The coast of Paraná is $105 \mathrm{~km}$ in length, between

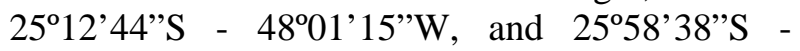
$48^{\circ} 35^{\prime} 26^{\prime \prime} \mathrm{W}$ (Fig. 1). Paranaguá and Guaratuba Bays are two large estuarine systems that include large freshwater inputs and relatively large quantities of both natural and anthropogenic organic and inorganic nutrients, which are then carried to the inner shelf, mainly during the rainy season (summer) (Noernberg, 2001). The continental shelf of Paraná is part of the South Brazil Bight (S.B.B.) and is relatively-broad, with a maximum width of $180 \mathrm{~km}$ off the Mel Island.

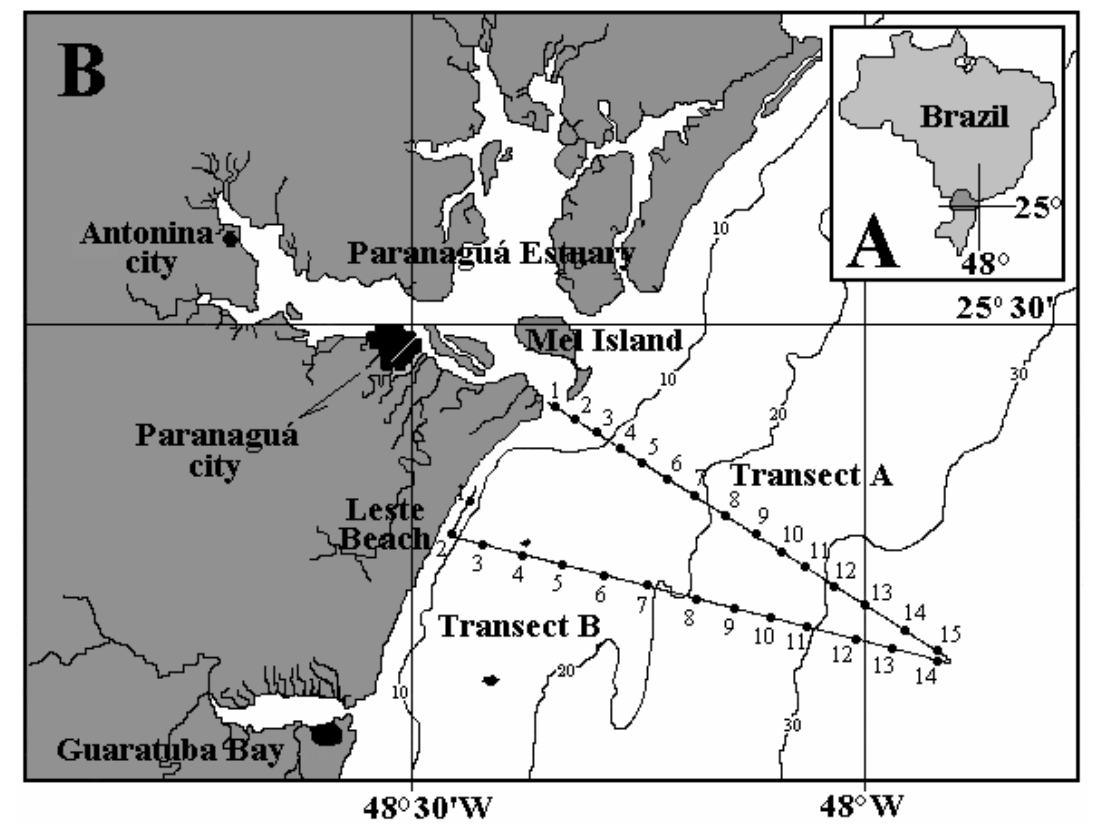

Figure 1 - Map of the study area. A) location of the study region in Brazil; B) organization of transects A and B on the coastal shelf.

Three water masses characterize the local hydrographic system: Coastal Waters (CW), Tropical Waters (TW) and South Atlantic Central Waters (SACW) (Castro Filho et al., 1987; Emilsson, 1961). TW are generally warm, oligotrophic surface waters, while SACW are cold but rich and found in the lower water column (Brandini et al., 1988; Brandini, 1990; Emilsson, 1961; Matsuura, 1986; Matsuura, 1996). Consequently, primary production in the pelagic 
ecosystem is relatively low in the upper layers, but may increase greatly in deeper waters at the nutricline level, where maximum levels of chlorophyll $a$ have been recorded in austral Summer (Brandini et al., 1988; Brandini, 1990).

\section{MATERIAL AND METHODS}

From November 1998 to March 1999, monthly sampling surveys were conducted using a S/V "Formalhaut" boat from the Brazilian Navy. Surface water was collected with a bucket, once per station per sample. Stations were sampled every 15 minutes along two transects established on the inner shelf, from the coast to 40 miles

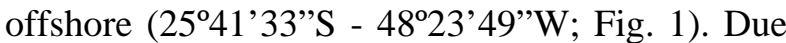
to climatic conditions of each trip, a minimum of 21 (in December) to a maximum of 25 (in November) locations were sampled.

Temperature was measured with a mercury thermometer and salinity was measured by refractometer (ATAGO, S/Mill, Japan). Rainfall and wind velocity were provided by the Marine Physics Laboratory of the Federal University of Paraná. Statistical analysis used the averages for rainfall and wind velocity calculated over a 4 day interval (i.e. the sampling day and the prior 3 days).

A random, $100 \mathrm{ml}$, sub-sample of the surface water was fixed with neutralized formalin solution $(0.4 \%)$ with Bengal Rose stain (18 to 20 drops of a $1 \mathrm{mg} / 100 \mathrm{ml}$ solution) for future phytoplankton and cyanobacteria counts. Samples were then kept in a sedimentation chamber for 24 hours after which they were examined with an inverted Zeiss microscope (Axiovert 100), following settling count technique (Utermöhl, 1958).

To count the number of filament groups, each sample was filtered through a $100 \mu \mathrm{m}$ mesh, collected in a square Petri dish and viewed with an Olympus (SZH) stereomicroscope. Average number of cells within a filament and average cell length were calculated from a random sample of 50 filaments selected among the total samples. The identification of $T$. erythraeum was made by the kind collaboration of Dr. Luciano Fernandes of the Federal University of Paraná. Chlorophyll- $a$ concentration was determined by fluorimetry, following Strickland and Parsons (1972). Due to technical problems, no chlorophyll- $a$ data were available for February 24, 1999, and thus average values were substituted on that day in the analyses to avoid missing values.

For the quantification of total bacteria, $15 \mathrm{ml}$ of water samples were immediately upon collection preserved in $4 \%$ formaldeyde p.A. Bacterial count and biomass quantification was done following Parsons et al. (1984), using the fluorochrome

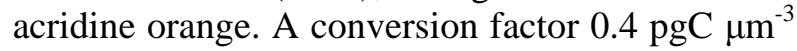
was used, following Bjørnsen and Kuparinen (1991). Cluster Analysis was conducted using original, centered and square-root transformed data (Clark and Warwick, 1994). The Bray-Curtis index of similarity was used for distance estimation and clusters were formed using the "unweighed pair-group average" method (UPGMA) (Legendre and Legendre, 1983; Ludwig and Reynolds, 1988; Clark and Warwick, 1994).

Main tendencies of variation were detected through Principal Component Analysis (PCA). Original data were natural $\log (\ln \mathrm{x})$ transformed and standardized. Linear correlation matrices of the biotic and abiotic variables with the plankton abundance were performed (Bouroche and Saporta, 1982; Ludwig and Reynolds, 1988). First, all stations were analyzed (PCA 1A and B - of the transects $\mathrm{A}$ and $\mathrm{B}$ ); then, only distant stations (Cluster II to IV in transect $\mathrm{A}$ and II to VI in transect $\mathrm{B}$ ) from the coast were analyzed (PCA 2A and $\mathrm{B}$ - of both transects). Missing data for stations located near the coast were replaced by the average value collected during all other months at the given station, while in the case of offshore stations, missing data were replaced by the value obtained at the prior station, in order to avoid missing data in the analyses. Since cells of $T$. erythraeum were extremely abundant, and hence difficult to count, the number of filaments was used instead of the number of cells as an estimation of abundance.

\section{RESULTS}

Water temperature varied from $24^{\circ} \mathrm{C}$ (Tansect A: Stations 1, 2, 3 and 4 on November 25, 1998) to $30^{\circ} \mathrm{C}$ (Transect B: Stations 8 and 9 on January 22, 1999). For both transects, lower temperatures were registered for the stations located between the infra-littoral and the $10 \mathrm{~m}$ isobath. The salinity varied from 25 (Transect A: Station 1 on March 24, 1999) to 40 (Transect A: Stations 11, 12, 13 and 14; Transect B: station 9, all on February 24, 
1999). Generally, salinity increased, mainly in and $40 \mathrm{~m}$ isobaths. transect $\mathrm{A}$, for the stations located between the 15

Table 1 - Daily arithmetical average of rainfall $(\mathrm{mm})$ and wind velocity $(\mathrm{m} / \mathrm{s})$ registered in the three days prior to sample (from Nov/98 to Mar/99), and during the sampled days.

\begin{tabular}{|c|c|c|c|c|c|c|}
\hline & Parameter & Nov./98 & Dec./98 & Jan./99 & Feb./99 & Mar./99 \\
\hline Rainfall & Absolute values & 1.8 & 0.0 & 0.0 & 16.0 & 4.1 \\
\hline & & 0.0 & 0.0 & 3.0 & 2.4 & 151.9 \\
\hline & & 0.1 & 0.1 & 4.2 & 8.6 & 53.9 \\
\hline & & 0.0 & 2.0 & 0.0 & 0.0 & 0.0 \\
\hline & Mean & 0.48 & 0.53 & 1.80 & 6.75 & 52.48 \\
\hline Wind & Absolute values & 5.15 & 3.44 & 2.08 & 2.62 & 2.44 \\
\hline & & 4.41 & 4.76 & 3.27 & 2.49 & 3.36 \\
\hline & & 6.09 & 5.85 & 3.13 & 2.96 & 2.40 \\
\hline & & 3.04 & 3.85 & 3.14 & 2.62 & 2.42 \\
\hline & Mean & 4.67 & 4.48 & 2.91 & 2.67 & 2.66 \\
\hline
\end{tabular}

\section{Transect A}

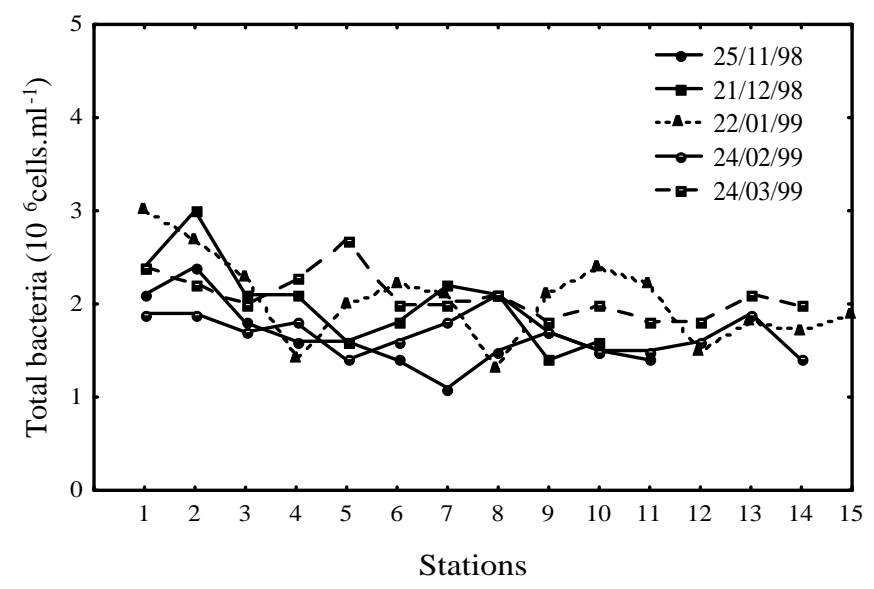

Transect B

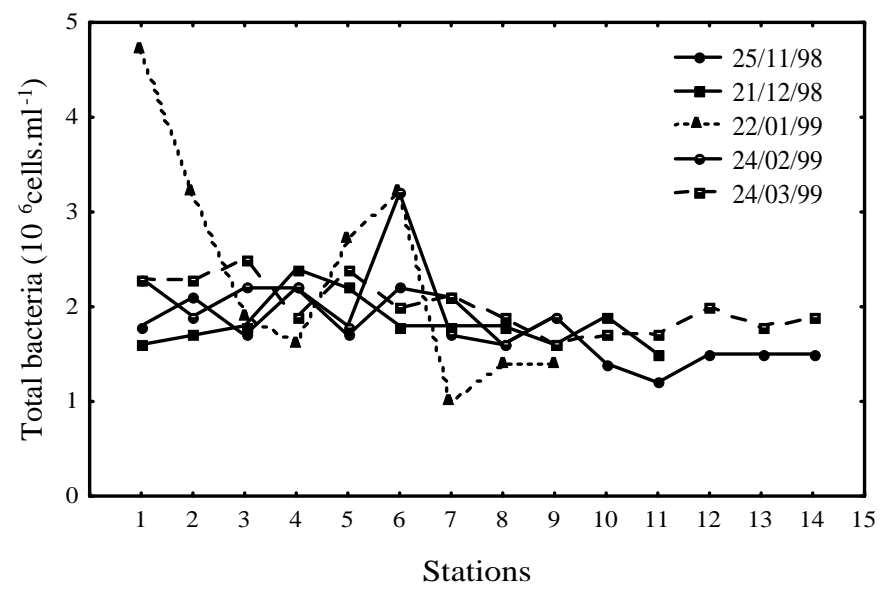

Figure 2 - Absolute values of cell density of total bacteria in the transects A and B. 
The lowest average rainfall was $0.48 \mathrm{~mm}$ (November 25, 1998) while the highest was 52.5 $\mathrm{mm}$ (March 24, 1999). The highest average wind velocity during the study period was $4.67 \mathrm{~m} / \mathrm{s}$ (November 25, 1998) and the lowest was $2.66 \mathrm{~m} / \mathrm{s}$ (March 24, 1999) (Table 1). The maximum point wind velocity never exceeded $6 \mathrm{~m} / \mathrm{s}$, and can therefore be considered weak winds [Marone, pers. com].

Average total bacterial density was $1.9 \times 10^{6}$ cells. $\mathrm{ml}^{-1}$ in transect $\mathrm{A}$, and $2.0 \times 10^{6}$ cells. $\mathrm{ml}^{-1}$ in transect B. The maximum density $\left(4.7 \times 10^{6}\right.$ cells. $\mathrm{ml}^{-1}$ ) was observed on January 22, 1999 at station 1 , transect $\mathrm{B}$, and the maximum $\left(1.0 \times 10^{6}\right.$ cells. $\mathrm{ml}^{-1}$ ) was observed on January 22, 1999 at station 7, transect B (Fig. 2). The common pattern during the study period comprised relatively high densities between the infra-littoral and the $10 \mathrm{~m}$ isobath, mainly in transect A (stations 1 to 3 ). Overall average bacterial biomass was $80.4 \mu \mathrm{gC} . \mathrm{l}^{-1}$ (Transect A), and $83.17 \mu \mathrm{gC.} .^{-1}$ (Transect B). The maximum was $217 \mu \mathrm{gC} .1^{-1}$ (Transect B: Station 1 on January 22, 1999) and the minimum was 49.1 $\mu \mathrm{gC} .1^{-1}$ (Transect A: Station 7 on November 25, 1998). Bacterial biomass was higher at all stations located between the infra-littoral and the $10 \mathrm{~m}$ isobath, mainly in transect $\mathrm{A}$, as was the case for total bacteria. Average chlorophyll- $a$ concentration was $2.47 \mu \mathrm{g} .1^{-1}$ in transect $\mathrm{A}$ and $1.96 \mu \mathrm{g} . \mathrm{l}^{-1}$ in transect B.

a)

\section{Transect A}

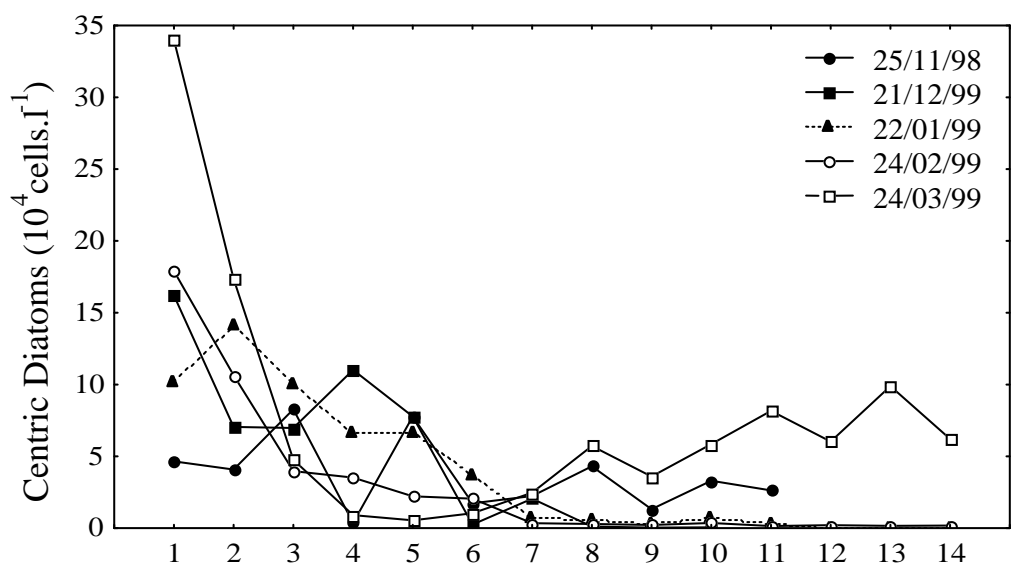

b)

\section{Transect B}

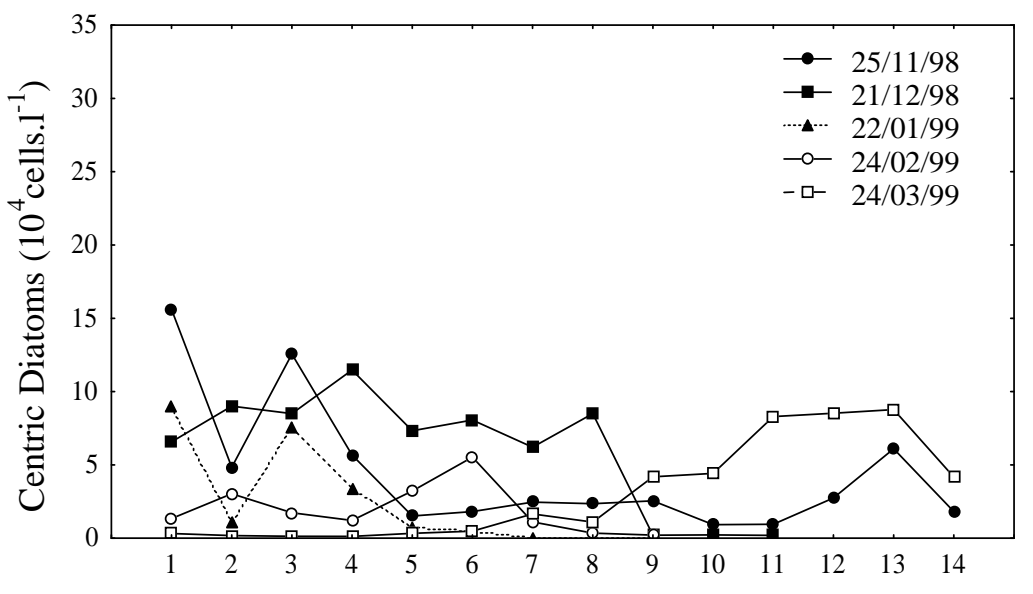


c)

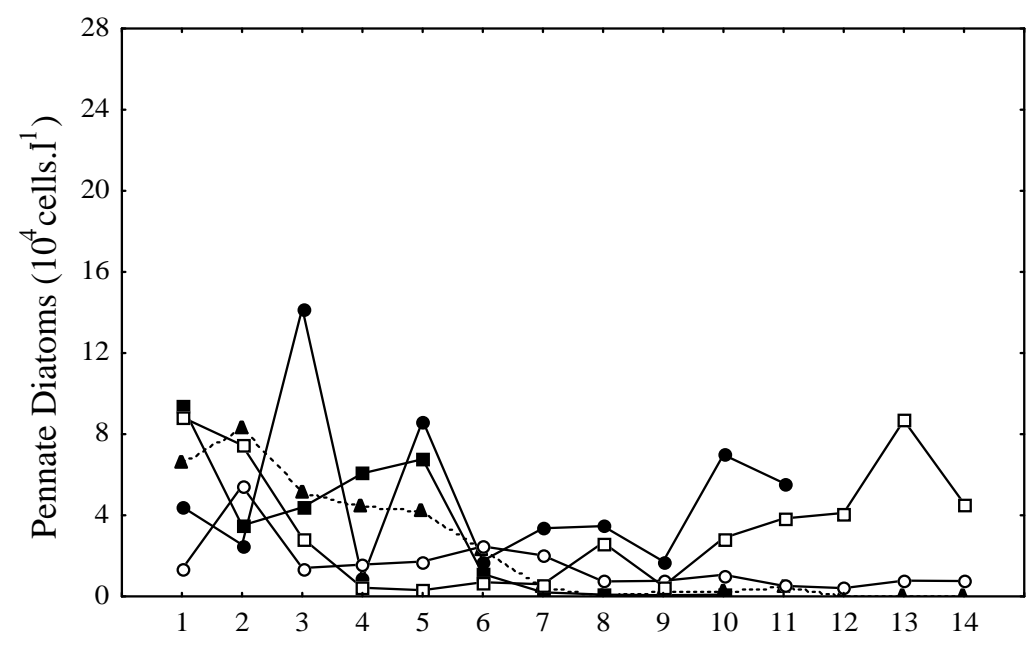

d)

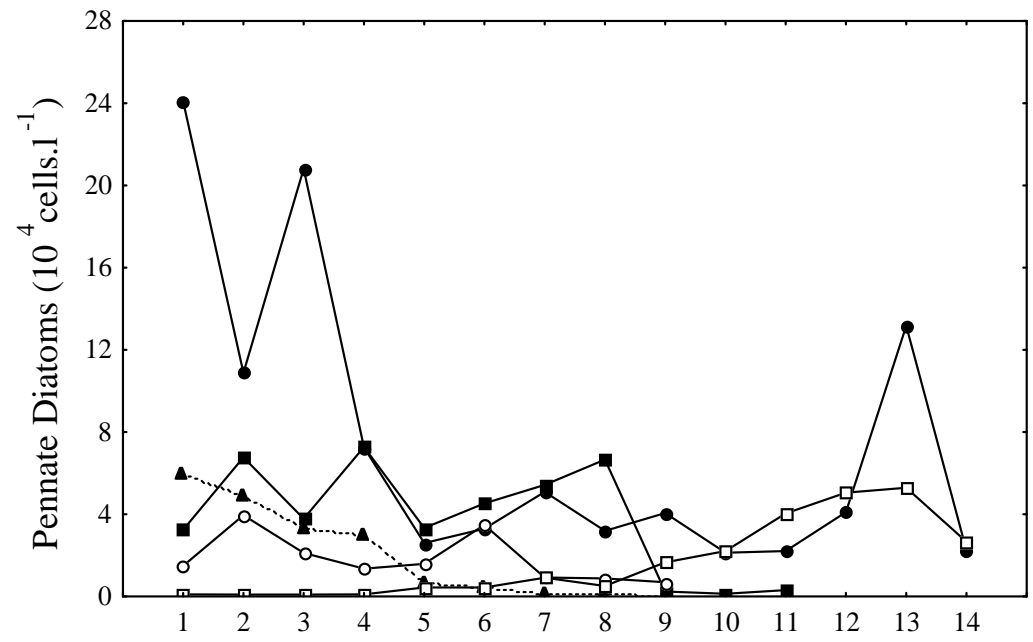

e)

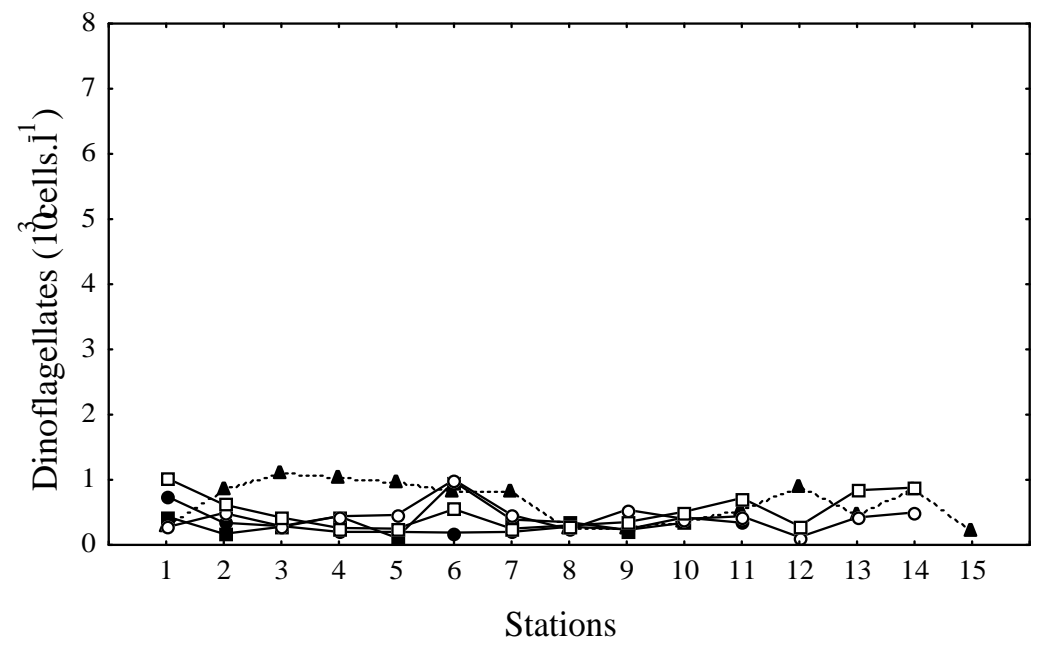

Brazilian Archives of Biology and Technology 
f)

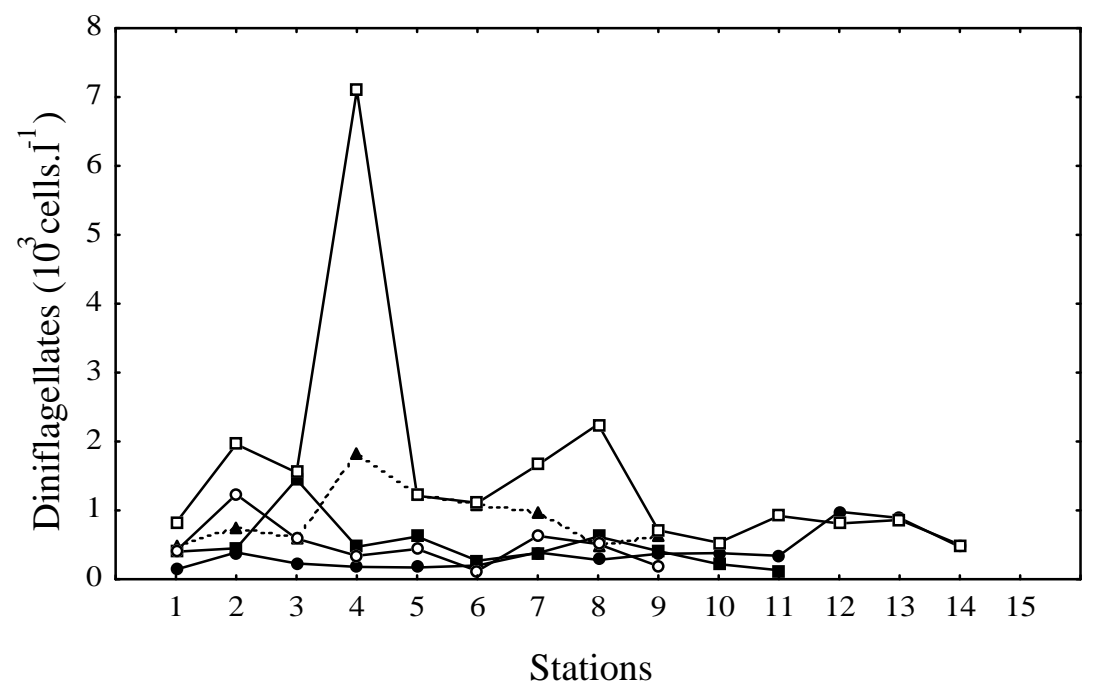

Figure 3 - Absolute values of cell density of: centric diatoms ( $a$ and b); pennate diatoms (c and d) and dinoflagellates (e and f) in the transects A and B.

a)

\section{Transect A}

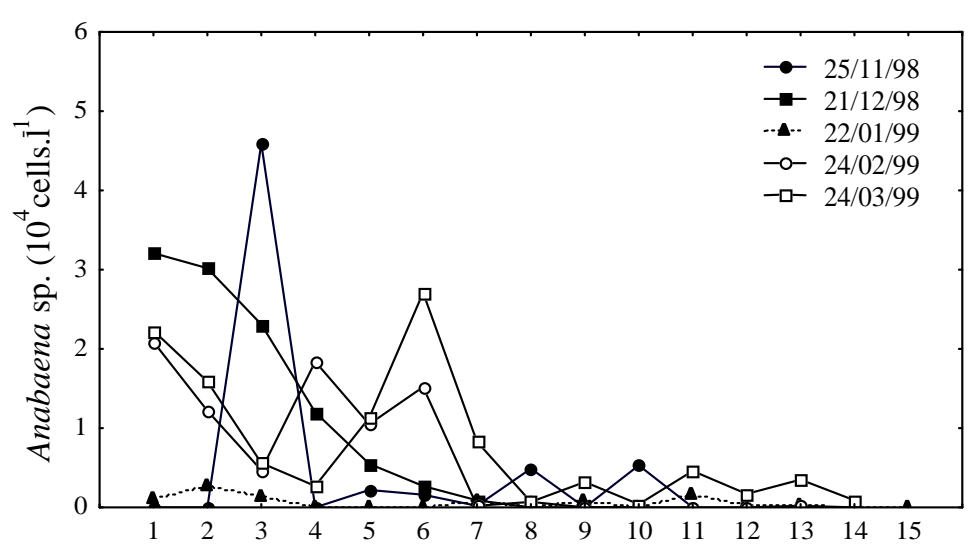

b)

Transect B

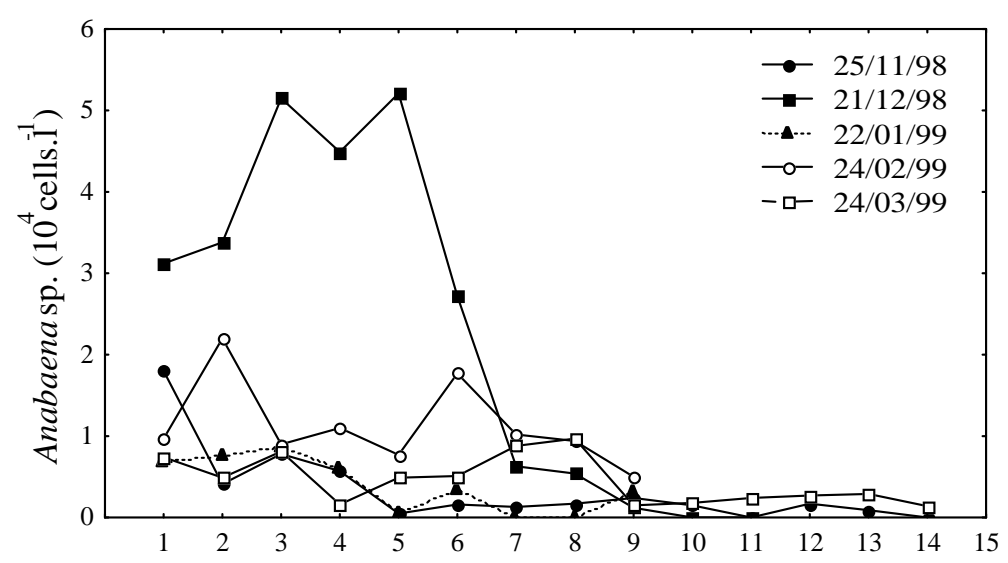


c)

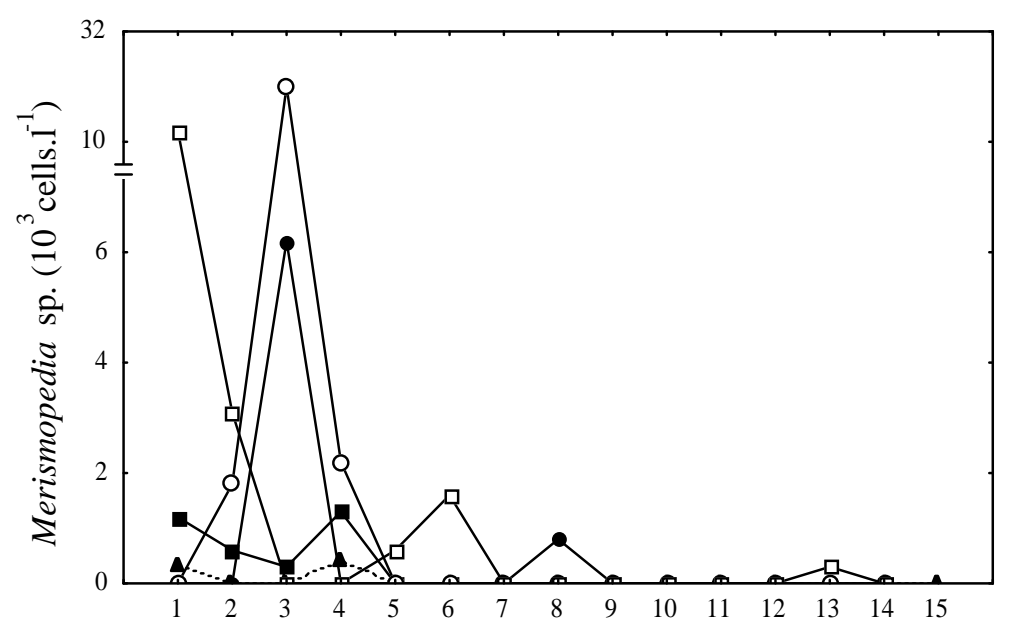

d)

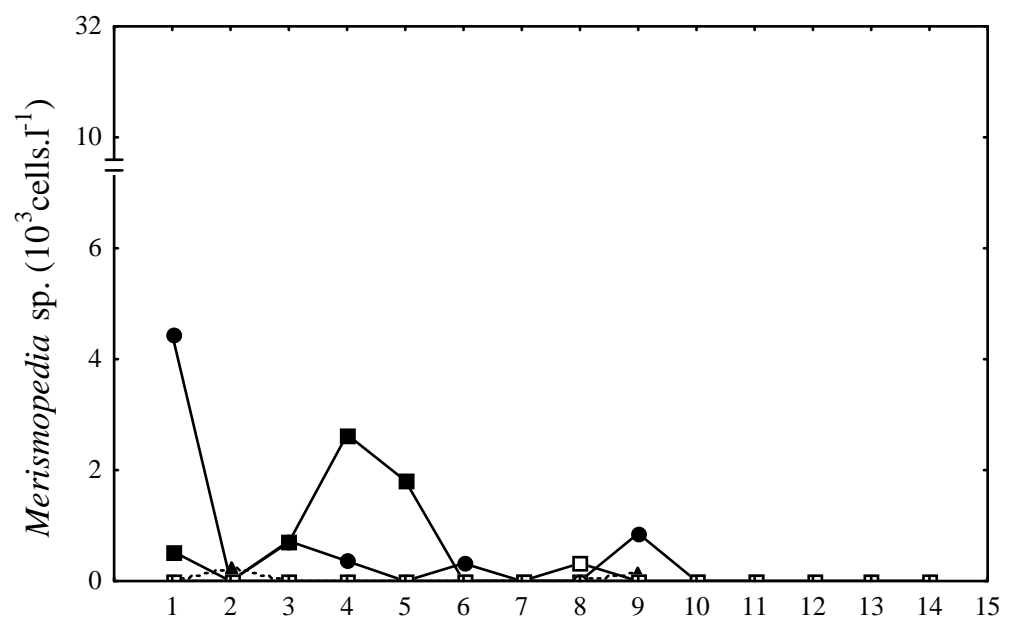

e)

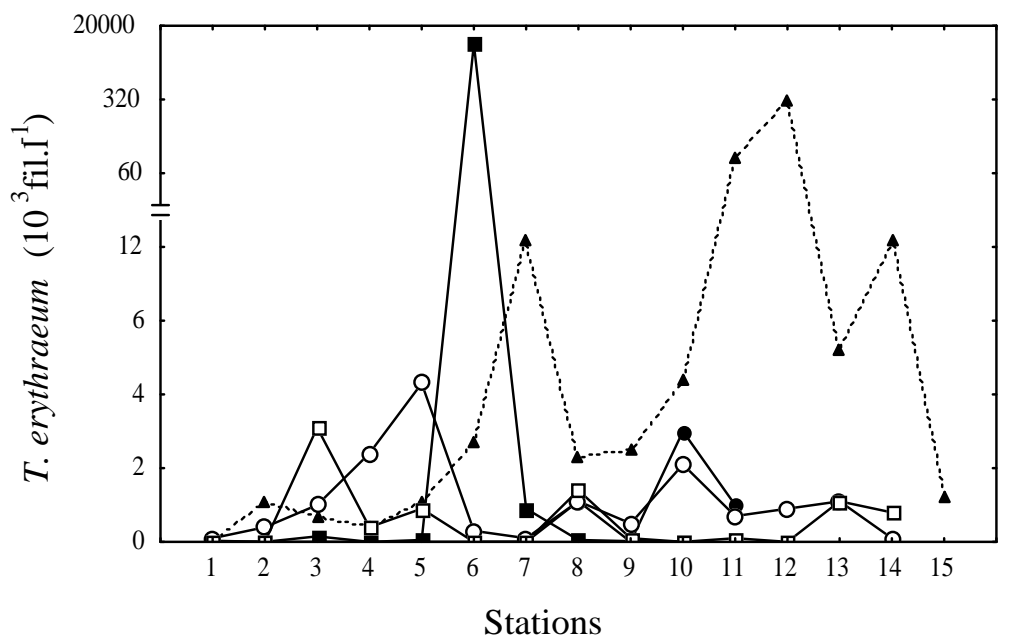


f)

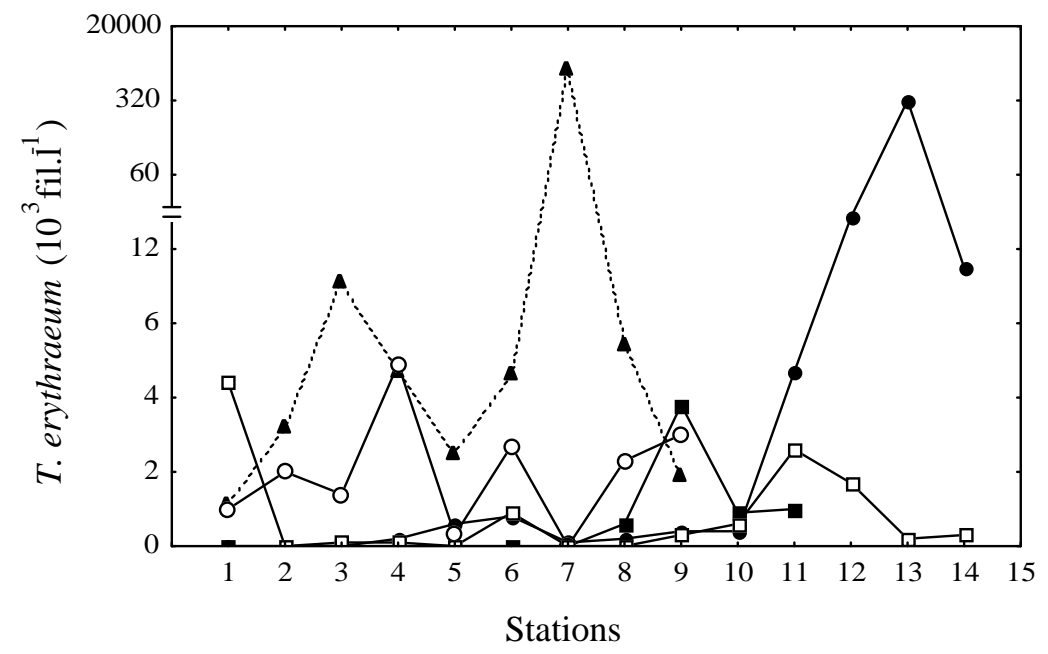

Figure 4 - Absolute values of cell density of: Anabaena sp. (a and b); Merismopedia sp. (c and d) and T. erythraeum ( $\mathrm{e}$ and $\mathrm{f}$ ) in the transects $\mathrm{A}$ and $\mathrm{B}$.

The highest concentration $\left(65.1 \mu \mathrm{g} . \mathrm{l}^{-1}\right)$ was observed at station 6 , transect $\mathrm{A}$, during a bloom of $T$. erythraeum on December 21, 1998. The lowest value $\left(0.29 \mu \mathrm{g} . \mathrm{l}^{-1}\right)$ was at station 9 , transect A, on January 22, 1999. In both transects, high values of chlorophyll- $a$ occurred at stations with blooms of T. erythraeum. Otherwise, value were relatively high from the coast to the $10 \mathrm{~m}$ isobath, mainly in transect A.

Centric and pennate diatom, and dinoflagellate abundances (maxima and minima) are described in Fig. 3. Average diatom densities were much higher extending from the coast to the $15 \mathrm{~m}$ isobath, after which they decreased towards the $40 \mathrm{~m}$ isobath. In contrast, dinoflagellate densities were relatively constant throughout the stations of transect A, while in transect B they were more abundant at stations 4 and 8 on March 24, 1999 and at stations with Trichodesmium blooms (Transect A: station 6 on December 21, 1998 and Stations 11 and 12 on January 22, 1999; Transect B: Stations 12 and 13 on November 25, 1998 and Station 7 on January 22, 1999).

Anabaena sp. and Merismopedia sp. (cyanobacteria) were abundant in both transects up to the $15 \mathrm{~m}$ isobath, then decreased with the distance from the shore. Maximum values were 52 x $10^{3}$ cells. $1^{-1}$ at station 5 , transect $\mathrm{B}$, on December 21,1998 , and $29 \times 10^{3}$ cells. $^{-1}$ on February 24, 1999, at station 3, transect A, respectively (Fig. 4 a, b, c, d). Both were often absent between the 20 and $40 \mathrm{~m}$ isobaths. None or few filaments of $T$. erythraeum were found in coastal stations (to the $15 \mathrm{~m}$ isobath), in late autumn and early spring. Blooms of these species were registered in late spring (November 25, 1998) and early summer (December 21, 1998 and January 22, 1999), between the $15 \mathrm{~m}$ and $40 \mathrm{~m}$ isobaths. A maximum of $19 \times 10^{6}$ fil. $^{-1}$ was registered at station 6 of transect A on December 21, 1998 (Fig. 4 e, f). Average length and average cell numbers of 50 randomly chosen filaments were $263 \mu \mathrm{m}$ and 52 cells, respectively.

The first component of the PCA related to transect A explained $27 \%$ of the total variation of the abiotic and biotic variables and showed a strong tendency for higher salinity at stations 8,9 and 10 on December 21, 1998 at stations 8, 9, 13 and 15 on January 22, 1999 and stations 5, 7, 8, 9, 10, 11, 12, 13 and 14 on February 24, 1999. Centric and pennate diatoms, Anabaena sp., total bacteria, bacterial biomass, and chlorophyll- $a$ were higher at stations 1, 2, and 3 on December 21, 1998, January 22, February 24, and March 24, 1999, station 4 on December 21, 1998 and station 13 on March 24, 1999 (Fig. 5 - PCA 1A).

The second principal component explained $17 \%$ of the variation. Rainfall, temperature, dinoflagellates, and T. erythraeum were higher at station 6 on December 21, 1998 and stations 11 and 12 on January 22, 1999, and Merismopedia $\mathrm{sp}$. was higher at all sampled stations in late autumn (November 25, 1998) (Fig. 5 - PCA 1A). 
The first component of the PCA related to transect B explained $29 \%$ of the variation. T. erythraeum abundance was higher at stations 7,8 , and 9 on January 22, 1999, and bacterial biomass, centric and pennate diatoms, and Merismopedia sp. were higher at stations $1,2,3,4,6$, and 7 on November 25, 1998, at stations 1, 2, 3, 4, 5, 6, and 7 in December 21, 1998, and at station 6 in February 24, 1999 (Fig. 5 - PCA 1B).

The second component from the PCA explained $22 \%$ of the variation, and associated temperature, rainfall, total bacteria, and dinoflagellates being higher at stations 1, 2, 3, 4, 5, and 6 on January 22, 1999, and all stations on March 24, 1999 (autumn). Salinity and chlorophyll- $a$ were higher at stations $5,8,10,11,12,13$, and 14 on November 25, 1998 (spring), and at stations 9, 10, and 11 on December 21, 1998 (early summer) (Fig. 5 - PCA 1B).

Cluster Analysis of the biotic variables of transect A formed the stations into four groups with a $10 \%$ dissimilarity. The first group of transect B, at $6 \%$ dissimilarity, included the four stations between the infralittoral and the $12 \mathrm{~m}$ isobath (Fig. 6). It is important to note that for both transects, group I included all stations influenced by the coastal environment and presenting relatively high values of biotic factors. Therefore, those stations (i.e. from 1 to 5 in transect A, and from 1 to 4 in transect $\mathrm{B})$ were excluded from the subsequent statistical analysis (i.e. PCA).

The first two principal components applied only to stations located between 15 and $40 \mathrm{~m}$ isobaths of transect $A$ and between 12 and $40 \mathrm{~m}$ isobaths of transect B explained $48 \%$ of data variation in transect A (stations 6 to 14), and $47 \%$ of data variation (stations 5 to 14 ) in transect B.

The first principal component of transect A explained $25 \%$ of variability. Correlation was positive for salinity, T. erythraeum and, to a lower extent, for bacterial biomass, temperature and chlorophyll $a$ in the majority of the stations during the summer and was positive for centric and pennate diatoms, Merismopedia sp., and Anabaena sp. at station 6 on February 24, 1999, and at all stations on March 24, 1999 (autumn). The second principal component of transect A explained 22\% of the variation. Positive relationships between rainfall, total bacteria, dinoflagellates, and for chlorophyll- $a$, temperature, and bacterial biomass were found at stations 6 and 7 on January 22, 1999 (Fig. 7 - PCA 2A).

In transect $\mathrm{B}$, the first component explained $25 \%$ of variability. Positive correlations were detected for T. erythraeum and chlorophyll- $a$ at: 1) stations 7 and 8 on January 22, 1999; 2) stations 8 and 9 in February 24, 1999 and to a lower extend at 3) stations 11 in November 25, 1998, and 4) stations 9, 10, and 11 in December 21, 1998. On the other hand, positive correlations of centric and pennate diatoms, total bacteria, bacterial biomass and Anabaena sp. were found at stations 6, 7, and 9 in November 25, 1998 at stations 5, 6, 7, and 8 in December 21, 1998 and at station 6 in February 24,1999 . The second component explained $22 \%$ of the variation and correlating salinity with 1) stations 5, 8, 10, 11, 12, 13, and 14 in November 25, 1998 (spring) and 2) stations 9, 10, and 11 in December 21, 1998. Temperature, rainfall, and dinoflagellates were inversely correlated with 1) stations 5, 6, and 9 in January 22, 1999, and 2) all stations in March 24, 1999 (autumn) (Fig. 7 PCA 2B).

\section{DISCUSSION}

The average drift current velocity off Mel Island was $11 \mathrm{~cm} / \mathrm{s}$ towards the north [Noernberg, pers. com.], suggesting that, in the absence of cold fronts, a particle could travel approximately 285 $\mathrm{km}$ within 30 days. Therefore, it was unlikely that the blooms of $T$. erythraeum observed over two consecutive months were the same. Although, in November 1998 and January 1999, blooms were registered in consecutive stations in transects $\mathrm{A}$ and B, that possibly could be isolated groups of $T$. erythraeum that came from a greater bloom that formed previously in the south.

Isolated filaments of $T$. erythraeum were also encountered throughout the study period. In January and February of 1999, they were characterized by relatively large numbers of trichomes, and filamentous cells were recorded in coastal stations, which suggested that warm months were associated with development of the cyanobacterium in this region. Realtively few filaments of T. erythraeum were found close to the coast (up to the $15 \mathrm{~m}$ isobath), especially during the months of November and December, 1998. 


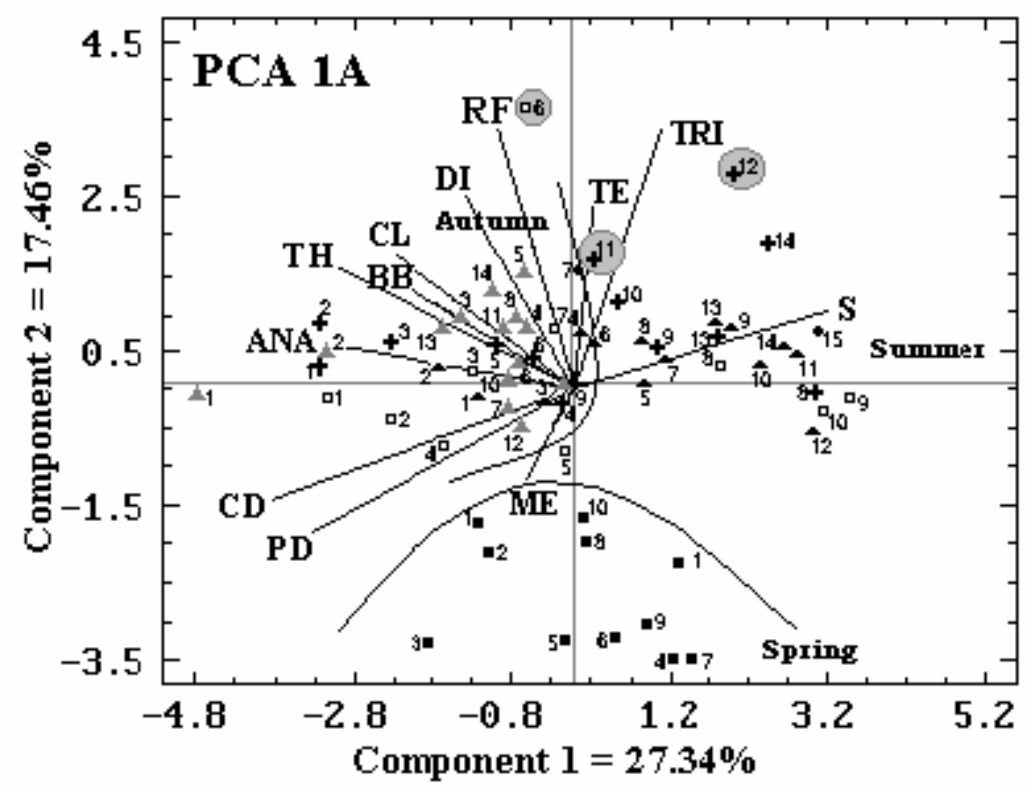

- November: estations 1-11 + January: estations 1-15 \& March: estations 1-14 a December: estations 1-10 \& February: estations 1-14 $\bigcirc$ Bloom

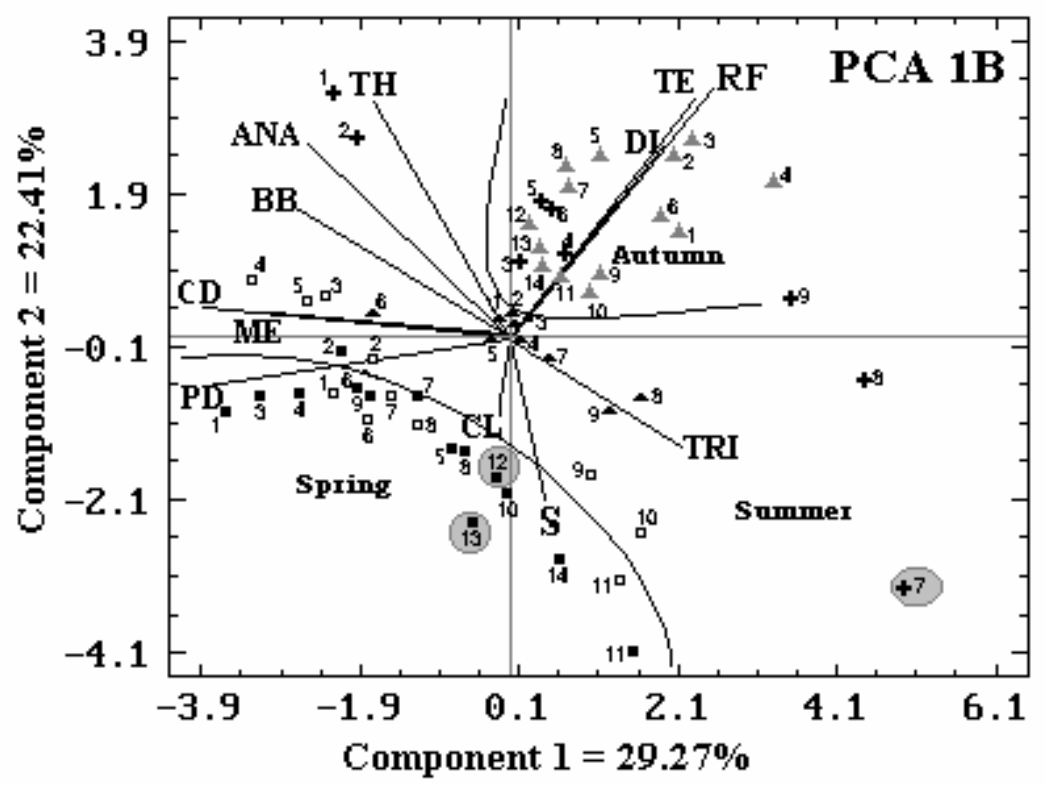

- November: estations 1-14 + January: estations 1-9 4 March: estations 1-14 - December: estations 1-11 \& February: estations 1-9 $\bigcirc$ Bloom

$\mathbf{S}=$ Salinity $; \mathbf{T E}=$ Temperature $\mathbf{P L}=$ Rainfall $; \mathbf{C L}=$ Chlorophyll $a ; \mathbf{C D}=$ Centric Diatoms $; \mathbf{P D}=$ Pennate Diatoms DI = Dinoflagellates; ANA =Anabaena sp.; ME =Merismopedia sp.; TRI =T . erythraeum; $\mathbf{T H}=$ Total Bacteria; $\mathbf{B B}=$ Bacterial Biomass.

Figure 5 - Distribution of sampled points and biotic and abiotic variables during the study period in transect A (PCA 1A) and B (PCA 1B), plotted by the first two Principal Components. 
A

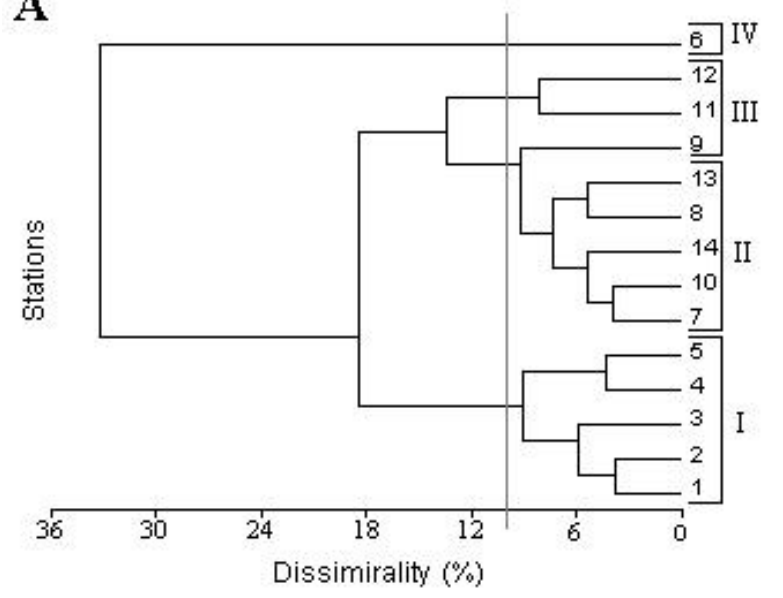

B

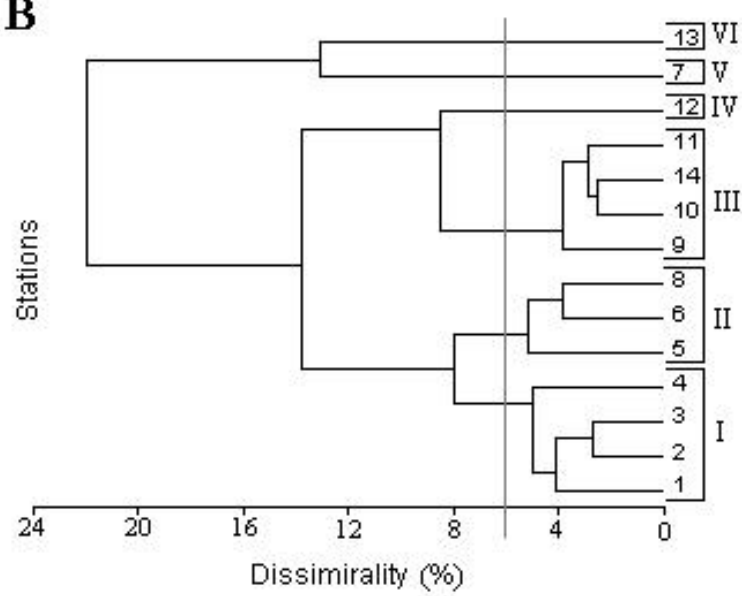

Figure 6 - Clusters from the group analysis of the study stations, based on the biotic measurements obtained between November/98 and March/99 in transects A and B. Numbers I, II, III, IV, $\mathrm{V}$, and VI indicate the station groups.

During the remainder of the study period, filament densities were relatively constant along both transects, except at the station that recorded blooms. However, centric and pennate diatoms, Anabaena sp. and Merismopedia sp. were common between the infralittoral and the $15 \mathrm{~m}$ isobath. This indicate that these phytoplankters and cyanobacteria needed nutrient-rich waters with low salinity to develop, unlike $T$. erythraeum that favored oligotrophic, saline waters (Brandini and Moraes 1986).

Cluster analyses suggested that nutrient-rich waters, originating from the Paranaguá estuarine system, could spread farther at transect A, which was closer to the river mouth. Consequently, abundance of the organisms that relied on dissolved organic nutrients to grow was higher in transect $\mathrm{A}$ than in transect $\mathrm{B}$. In stations that did not experience blooms of $T$. erythraeum, concentrations of dinoflagellates were relatively stable, except in March 1999 in transect B where cell densities were highest up to regions contiguous to the $12 \mathrm{~m}$ isobath. Dinoflagellates were relatively more abundant in Summer, early Autumn and in the vicinity of $T$. erythraeum blooms. Although results refers to total dinoflagelates, heterotrophic dinoflagelates could also be considered that, according to Strasburger et al. (1983), fed on planktonic bacteria and algae. No data are apparently available that describe whether dinoflagellates feed on $T$. erythraeum. Associations between these organisms and the blooms suggest that they may consume cyanobacteria, heterotrophic bacteria, or heterotrophic nanoflagellates. Furthermore, similarly to $T$. erythraeum, they found an ideal habitat and multiplied. On the other hand, it was possible that dinoflagellates utilized the nitrogen fixed by the Trichodesmium in nitrogen poor waters.

The PCA results applied to off-coast sampling points of transect A showed a positive correlation between blooms of $T$. erythraeum and environmental parameters such as salinity, temperature and chlorophyll- $a$. The PCA analysis also showed a positive correlation between the cyanobacteria bloom and bacterial biomass. According to Mesquita (1993), healthy alive phytoplankton repel bacteria cells, however, when die under situations of nutrient limitation, phytoplankton cells may be attacked by bacteria. Thus, phytoplankton are directly converted in detrite and bacterial biomass. The gas vacuoles present in T. erythreum cells enable them to stay on the surface even in scenescence. Statistical analysis did not detect any significant variation on total bacterial population among the blooms detected, neither on transects $\mathrm{A}$ and $\mathrm{B}$, nor on the other oceanic sampling stations. These results led to the conclusion that the blooms were at their maximum development stage. The results showed that the T. erythraeum blooms occurred in calm periods at the end of spring and summer seasons. 


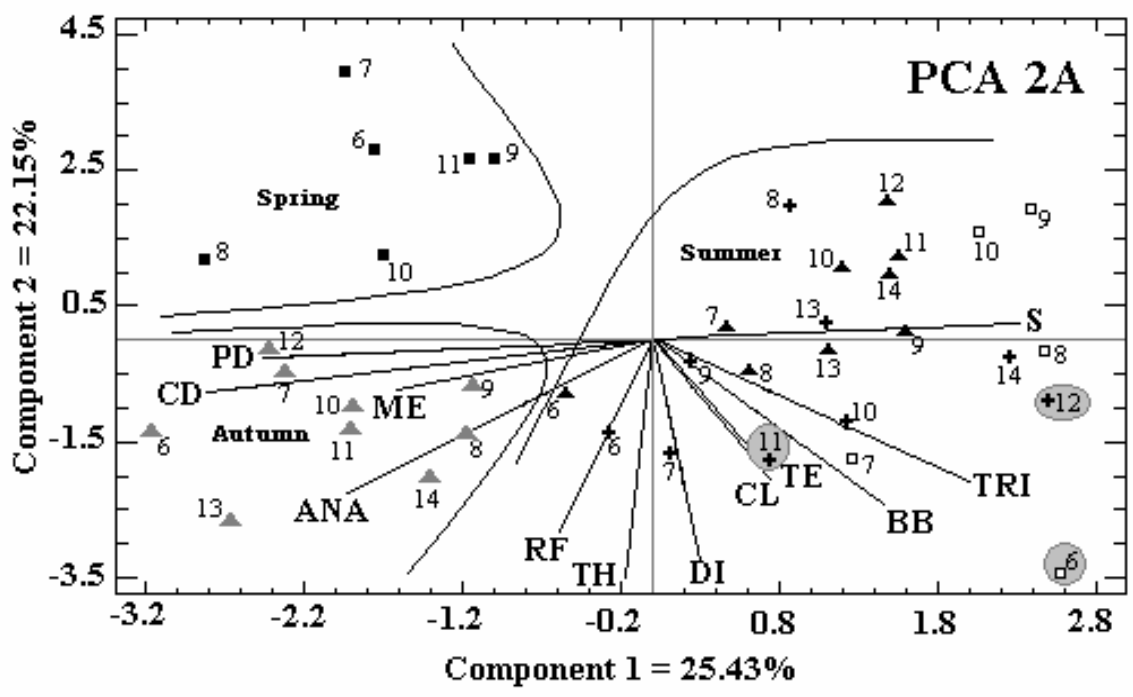

- November: estations 6-11 + January: estations 6-14 4 March: estations 6-14 व December: estations 6-10 \& February: estations 6-14 $\bigcirc$ Bloom

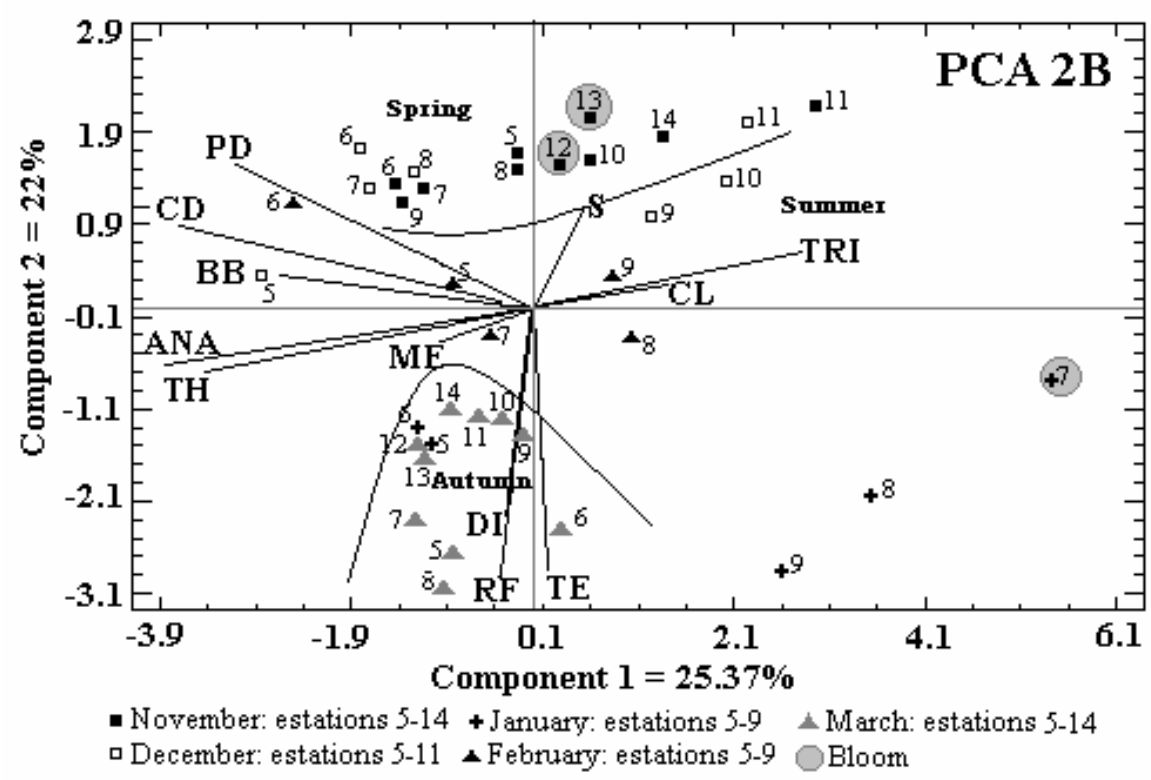

$\mathbf{S}=$ Salinity $; \mathbf{T E}=$ Temperature $\mathbf{P L}=$ Rainfall $; \mathbf{C L}=$ Chlorophyll $a ; \mathbf{C D}=$ Centric Diatoms $; \mathbf{P D}=$ Pennate Diatoms DI = Dinoflagellates; ANA =Anabaena sp.; ME =Merismopedia sp.; $\mathbf{T R I}=T$. erythraeum; $\mathbf{T H}=$ Total Bacteria; $\mathbf{B B}=$ Bacterial Biomass.

Figure 7 - Distribution of sampled points, and of the biotic and abiotic values of the stations distant from the coast in transect A (PCA 2A) and transect B (PCA 2B) with the axes being the first two principal components.

No cyanobacteria bloom was detected at the end of summer and begining of autumn.

During the summer period, the Brazilian Current with oligotrophic waters mix-up with the Coastal Continental Shelf Waters (CCSW) of Paraná State, making them nutrient poor waters and favoring the development of $T$. erythraeum blooms. With the increase of salinity and temperature of surface water masses, the biggest bloom was observed at 10 and $20 \mathrm{~m}$ isobath. The present results 
confirmed that blooms of $T$. erythraeum formed along Paraná coast and also confirmed the findings of Lee (1989), Bell (1992) and Rörig et al. (1998) that $T$. erythraeum was a nitrogen-fixing and silicate free growing organism; its photosynthesis was performed at high light intensities and it was adapted to survive in areas with low competition, different from other cyanobacteria.

\section{ACKNOWLEDGEMENTS}

The authors are grateful to the Coordenação de Aperfeiçoamento de Pessoal de Nivel Superior (CAPES) for the graduate fellowship and Capitania dos Portos do Estado do Paraná for providing logistical support. We also thank Dr. Luciano Fernandes for his help on cyanobacteria identification, MSc. Nilva Brandini for her valuable contribution with phytoplankton analysis, Dr. Marco Fábio Maia Corrêa for his pertinent comments on the manuscript, and Dr. Ricardo de Queiroz, Dr. Theresinha Monteiro Absher and Dr. James Roper for reviewing the English.

\section{RESUMO}

O propósito principal da presente pesquisa foi investigar as florações de Trichodesmium erythraeum na plataforma continental interna do Estado do Paraná, Brasil. Foram medidas, em águas de superfície a temperatura, salinidade, bactérias totais, biomassa bacteriana, clorofila- $a$, densidade fitoplanctônica, densidade das cianobactérias Anabaena sp., Merismopedia sp. e T. erythraeum. Ao contrário dos dinoflagelados, cuja abundância foi relativamente constante em todas as estações, as diatomáceas cêntricas e penadas, Anabaena sp. e Merismopedia sp. foram mais abundantes até a isóbata dos $15 \mathrm{~m}$. A densidade de bactérias totais também foi relativamente homogênea na área amostrada, o que sugere que as florações de T. erythraeum não se encontravam em fase senescente. Os resultados confirmam que $T$. erythraeum é capaz de sobreviver em condições ambientais relativamente inóspitas devido à sua capacidade de fixar nitrogênio e efetuar a fotossíntese em altas intensidades de luz.

\section{REFERENCES}

Barbrook, A. C.; Lockhart P. J. and Howe C. J. (1998), Phylogenetic analysis of plastid origins based on secA sequences. Current Genetic, 34, 336-341.

Bell, P. R. F. (1992), Eutrophication and coral reefs: some examples in the Great Barrier Reef lagoon. Water Res., 26 : (5), 553-568.

Bidandda, B. (1997), Trichodesmium bloom in Gulf of Mexico, Summer 1995. In: Harmful Algae News (IOC), 12/13, 2.

Bjørnsen, P. K. and Kuparinen, A. (1991), Determination of bacterioplankton biomass, net production and growth efficiency in the southern ocean. Mar. Ecol. Prog. Ser., 71, 185-194.

Bouroche, J. M. and Saporta, G. (1982), Análise de dados. Rio de Janeiro: Zahar.

Brandini, F. P. and Moraes, C. L. B. (1986), Composição e distribuição do fitoplâncton em áreas costeiras e oceânicas da Região Sueste do Brasil. Nerítica, 1 : (3), 9-19.

Brandini, F. P. (1988), Composição e distribuição do fitoplâncton na região Sueste do Brasil e suas relações com as massas de água (Operação Sueste julho/agosto 1982). Cienc. Cult., 40 : (4), 334-341.

Brandini, F. P.; Moraes, C. L. B. and Thamm, C. A. (1988), Shelf break upwelling, subsurface maxima of chlorophyll and nitrite, and vertical distribution of a subtropical nano- and microplankton community off southeastern Brazil (November 1985). In: Encontro Brasileiro de Plâncton, 3., Caiobá. Anais... Caiobá, Paraná.

Brandini, F. P. (1990), Hydrography and characteristics of the phytoplankton in shelf and oceanic waters off Southeastern Brazil during Winter (July/August 1982) and Summer (February/March 1984). Hydrobiologia, 196, 111-148.

Castro Filho, B. M.; Miranda, L. B. and Myiao, S. Y. (1987), Condições hidrográficas na plataforma continental ao largo de Ubatuba: variações sazonais e em média escala. Bol. Inst. Oceanogr., 35 : (2), 135-151.

Clark, K. R. and Warwick, R. M. (1994), Change in marine communities: an approach to statistical analysis and interpretation. Natural Environment Research Council, UK.

Companhia de Tecnologia de Saneamento Ambiental (2000), Florações de Algas Azuis (Trichodesmium erythraeum) no Litoral dos Estados de São Paulo e Paraná. São Paulo: CETESB. (Relatório Técnico).

Doyle, J. J. (1998), Phylogenetic perspectives on nodulation: evolving views of plants and symbiotic bacteria. Trends in Plant Science, 3, 473-478.

Emilsson, I. (1961), The shelf and coastal waters off southern Brasil. Bol. Inst. Oceanogr., 11, 101-112. 
Fernandes, L. F. and Brandini, F. P. (1999), Comunidades microplanctônicas no Oceano Atlântico Sul Ocidental: biomassa e distribuição em novembro de 1992. Rev. Bras. Oceanogr., 47 : (2), 189-205.

Gianesella-Galvão, S. M. F.; Costa, M. P. F. and Kutner, M. B. (1995), Bloom de Oscillatoria (Trichodesmium) erythraea (Ehr.) Kutz. in coastal waters of the Southweast Atlantic. Publ. Esp. Inst. Oceonograf., 11, 133-140.

Kolm, H. E.; Schoenenberger, M. F.; Piemonte, M. R. P.; Souza, S. A.; Schnell and Scuhli, G.; Mucciato, M. B. and Mazzuco, R. (2002), Spatial Variation of Bacteria in Surface Waters of Paranaguá and Antonina Bays, Paraná, Brazil. Braz. Arch. Biol. Technol., 45 : (1), 27-34.

Kutner, M. B. and Sassi, R. (1978), Dinoflagellates from the Ubatuba region (Lat. $20^{\circ} 30^{\prime} \mathrm{S}-45^{\circ} 60^{\prime} \mathrm{W}$ ). In: Brandini, F. P., Lopes, R. M.; Gutseit, K. S.; Spach, H. L and Sassi, R. (1997), Planctonologia na Plataforma Continental do Brasil. Revizee Avaliação do Potencial Sustentável de Recursos Vivos na Zona Econômica Exclusiva.

Lee, R. E. (1989), Phycology. 2. ed. New York: Cambridge University Press. pp. 55-93.

Legendre, L. and Legendre, P. (1983), Numerical Ecology. Amsterdam; Oxford; New York: Elsevier Scientific Publ. Company.

Ludwig, J. A. and Reynolds, J. F. (1988), Statistical ecology. A primer methods and computing. John Wiley and Sons.

Matsuura, Y. (1986), Contribuição ao estudo da estrutura oceanográfica da região sudeste entre Cabo Frio (RJ) e Cabo de Santa Marta Grande (SC). Cienc. Cult., 38 : (8), 1439-1450.

Matsuura, Y. (1996), A probable cause of recruitment failure of the brazilian sardine Sardinella aurita population during the $1974 / 75$ spawning season. $S$. Afr. J. mar. Sci., 17, 29-35.

Mesquita, H. S. L. (1993), Densidade e distribuição do bacterioplâncton nas águas de Ubatuba $\left(23^{\circ} \mathrm{S} 45^{\circ} \mathrm{W}\right)$, Estado de São Paulo. Bol. Inst. Oceanogr., 10, 45-63.

Noernbeng, M. A. (2001), Processos Morfodinâmicos no Complexo Estuarino de Paranaguá - Paraná Brasil: um estudo a partir de dados in situs e LandsatTM . Tese (Doutorado), Universidade Federal do Paraná, Paraná, Brasil.
Parsons, T. R.; Maita, Y. and Lalli, C. M. (1984), Direct Counting of Bacteria by Fluorescence Microscopy. In: A Manual of Chemical and Biological Methods for Seawater Analysis. Pergamon Press.

Richardson, K. (1997), Harmful or exceptional phytoplankton blooms in the marine ecosystem. $A d v$. Mar Biol., 31, 301-385.

Rörig, L. R.; Yunes, J. S.; Kuroshima, K. N.; Schetinni, C. A. F.; Pezzuto, P. R. and Proença, L. A. O. (1998), Studies on the ecology and toxicity of Trichodesmium spp. Blooms in southern brazilian coastal waters. Harmful Algae, UNESCO.

Rosa, Z. M. and Bucelato,T. C. (1981), Sobre a ocorrência de floração de Gyrodinium aereolum Hulburt (Dynophycea) no litoral sul do Estado do Rio Grande do Sul. Iheringia - Botânica, 21, 169-179.

Satô, S.; Paranaguá, M. N. and Eskinazi, E. (1963), On the mechanism of the red tide Trichodesmium. In: Recife northeastern Brazil, with some considerations of the relation to the human disease "Tamandaré Fever". Trab. Oceanogr. Univ. Fed., PE, 5, 7-49.

Strasburger, E.; Noll, F.; Schenck, H. and Schimper, A. F. W. (1983), Lehrbuch der Botanik. Gustav. Fischer. Verlag., Stuttgart, New York.

Strickland, J. L. H. and Parsons, T. R. (1972), A Practical Handbook of Sea water Analysis $2^{\text {nd }}$ Bull Fish Res. Bd. Can., 122, 1-172.

Utermöhl, H. (1958), Zur Vervollkomnung der quantitativen phytoplankton. Methodik. Mitt. int. Ver. theor. angew. Limnol., 9, 1-3.

Received: September 09, 2004; Revised: February 22, 2005; Accepted: January 09, 2006. 